\title{
A retrospective case-control study of hepatitis $C$ virus infection and oral lichen planus in Japan: association study with mutations in the core and NS5A region of hepatitis $C$ virus
}

Yumiko Nagao ${ }^{1 *}$ and Michio Sata ${ }^{1,2}$

\begin{abstract}
Background: The aims of this study were to assess the prevalence of hepatitis C virus (HCV) infection in Japanese patients with oral lichen planus and identify the impact of amino acid (aa) substitutions in the HCV core region and IFN-sensitivity-determining region (ISDR) of nonstructural protein 5A (NS5A) associated with lichen planus.

Methods: In this retrospective study, 59 patients (group 1-A) with oral lichen planus among 226 consecutive patients who visited our hospital and 85 individuals (group 1-B, controls) with normal oral mucosa were investigated for the presence of liver disease and HCV infection. Risk factors for the presence of oral lichen planus were assessed by logistic regression analysis. We compared aa substitutions in the HCV core region (70 and/or 91) and ISDR of NS5A of 12 patients with oral lichen planus (group 2-A) and 7 patients who did not have oral lichen planus (group 2-B) among patients (high viral loads, genotype 1b) who received interferon (IFN) therapy in group1-A.

Results: The prevalence of anti-HCV and HCV RNA was 67.80\% (40/59) and 59.32\% (35/59), respectively, in group 1A and $31.76 \%(27 / 85)$ and $16.47 \%(14 / 85)$, respectively, in group 1-B. The prevalence of anti-HCV $(P<0.0001)$ and HCV RNA $(P<0.0001)$ in group 1-A was significantly higher than those in group 1-B. According to multivariate analysis, three factors - positivity for HCV RNA, low albumin level $(<4.0 \mathrm{~g} / \mathrm{dL})$, and history of smoking - were associated with the development of oral lichen planus. The adjusted odds ratios for these three factors were 6.58 , 3.53 and 2.58, respectively, and each was statistically significant. No significant differences in viral factors, such as aa substitutions in the core region and ISDR of NS5A, were detected between the two groups (groups 2-A and -B).

Conclusion: We observed a high prevalence of HCV infection in patients with oral lichen planus. Longstanding $\mathrm{HCV}$ infection, hypoalbuminemia, and smoking were significant risk factors for the presence of oral lichen planus in patients. It is advisable for Japanese patients with lichen planus to be tested for HCV infection during medical examination.
\end{abstract}

\section{Background}

Hepatitis $\mathrm{C}$ virus (HCV) infection is a major public health problem because it causes chronic hepatitis, cirrhosis and hepatocellular carcinoma (HCC). In Japan, elderly patients are at a higher risk for HCC and hepatitis $\mathrm{C}$ viral eradication has a smaller effect on hepatocarcinogenesis in older patients [1]. In Japan, refractory

\footnotetext{
* Correspondence: nagao@med.kurume-u.ac.jp

'Department of Digestive Disease Information \& Research, Kurume University

School of Medicine, Kurume, Fukuoka 830-0011, Japan

Full list of author information is available at the end of the article
}

cases with genotype $1 \mathrm{~b}$ and high viral loads are seen in as many as $70 \%$ of chronic hepatitis $\mathrm{C}$ patients.

Recent studies have identified both viral and host factors predictive of the outcome of interferon (IFN) therapy. Among the viral factors, the number of substitutions in the region amino acids (aa) 2209-2248 (IFN-sensitivity-determining region, ISDR, of nonstructural protein $5 \mathrm{~A}$, NS5A, in HCV genotype $1 \mathrm{~b}$ ) is associated with a sustained virological response (SVR) after IFN treatment of $\mathrm{HCV}$ genotype $1 \mathrm{~b}$ patients $[2,3]$. In addition, Akuta et al. reported that aa substitution at 
position 70 and/or 91 in the $\mathrm{HCV}$ core region in patients infected with HCV genotype $1 \mathrm{~b}$ are independent predictors of SVR and non-virological response (NVR) [4,5] and also affect hepatocarcinogenesis [6].

$\mathrm{HCV}$ mainly affects the liver but there are several extrahepatic manifestations of chronic HCV infection, including hematologic diseases such as cryoglobulinemia and lymphoma, renal disease such as membranoproliferative glomerulonephritis, autoimmune disorders such as thyroiditis, and dermatologic conditions such as lichen planus and porphyria cutanea tarda [7-10].

Lichen planus is a chronic inflammatory disease that affects the skin and oral mucosa. The association of lichen planus with HCV infection has been reported widely in the literature [11-16]. In particular, the relationship between lichen planus and HCV has been suggested by studies from Japan, Italy, Spain, and Brazil, indicating a strong geographic relationship [11-16]. We first reported a relationship between HCV and lichen planus in Japan [12]. Previous reports indicated that there are no differences in the viral factors such as viral load and genotype between $\mathrm{HCV}$-infected patients with lichen planus and those without $[17,18]$.

This study was conducted to determine the rate of $\mathrm{HCV}$ infection in individuals with lichen planus, and with normal oral mucosa as a control group, and to investigate the impact of aa substitutions in the HCV core region (70 and/or 91) and ISDR of NS5A among $\mathrm{HCV}$-infected patients with lichen planus and those without.

\section{Materials and methods Group 1 (Patients)}

A total of 226 consecutive patients had checkups for oral mucosal diseases in the Digestive Diseases Center at Kurume University Hospital Japan from February 2, 2010 to June 28, 2011. In this Digestive Diseases Center, physicians, surgeons, radiologists and an oral surgeon examine each patient in their own specialized area. An oral surgery specialist diagnosed 59 of 226 patients with oral lichen planus clinically and/or histopathologically. These 59 patients then consulted a liver specialist in the same center for the presence or absence of liver disease. The 59 patients (group 1-A) ranged in age from 32 to 87 years, with an average age of $68.05 \pm 9.93$ years. There were 14 men and 45 women.

\section{Group 1 (Controls)}

We have continued carrying out health screenings of the residents of $\mathrm{X}$ town (adult population: 7,389), in northern Kyushu, Japan where the prevalence of HCV infection is the highest in the country [19]. We reported previously that the residents had a high prevalence of $\mathrm{HCV}$ infec- tion, that $\mathrm{HCV}$ infection was the principal cause of liver disorders, and that extrahepatic manifestations were strongly associated with HCV infection [19-28].

In the previous study of 509 residents selected randomly, the prevalence of antibodies to $\mathrm{HCV}$ (anti-HCV), HCV RNA, and hepatitis B surface antigen ( $\mathrm{HBsAg}$ ) was $23.6 \%, 17.9 \%$, and $2.6 \%$, respectively [19]. We conducted cohort studies from August 1990 to May 2002 on the long-term prognosis of $\mathrm{HCV}$ carriers based on the same subjects in the town and investigated the risk factors for deaths due to HCC and liver cirrhosis [24,25].

One hundred and thirty nine subjects who had received a liver disease examination in 2002 were interviewed in person by two trained interviewers and all but one of them were given an oral mucosal examination by an oral surgeon. We used the headband fiber (50-100-10, Daiichi Medical Co., Ltd.) that had a brightness of 34,000 luces for mucosal examination. In this report, we used a control group consisting of 85 age- and gender- matched individuals (group 1-B) with normal oral mucosa, selected from the 139 subjects. The individuals ranged in age from 52 to 90 years, with an average age of $66.35 \pm 9.83$ years. We inquired about the following information: present health condition, medical treatment received in the hospital, name of the family doctor, the kind of medicine taken, and the presence of extrahepatic manifestations of $\mathrm{HCV}$ infection such as diabetes mellitus and thyroid dysfunction. We also asked the family doctors of the subjects about the presence of extrahepatic manifestations.

\section{Group 2 (Patients)}

The subjects were 19 patients with high titers of genotype $1 \mathrm{~b}$ (over $100 \mathrm{KIU} / \mathrm{mL}$ or $5.0 \log \mathrm{IU} / \mathrm{mL}$ ) who were investigated for aa substitutions in the HCV core region $(70$ and/or 91) and ISDR of NS5A. These were non-SVR patients among the 226 patients of group 1 who were not able to eradicate an $\mathrm{HCV}$ during past IFN therapy. We compared the characteristics of 12 patients who had lichen planus (group 2-A) and 7 patients who did not have lichen planus (group 2-B). Group 2 comprised 5 men and 14 women ranging in age from 44 to 73 years (average $64.47 \pm 8.48$ ).

\section{Methods}

\section{Serological assays}

Serum samples from the 144 subjects, including 59 patients with lichen planus and 85 people with normal oral mucosa, were tested for platelets (PLT) and hemoglobin $(\mathrm{Hb})$, and for the following liver function tests: serum alanine aminotransferase (ALT), aspartate aminotransferase (AST), lactate dehydrogenase (LDH), alkaline phosphatase (ALP), total bilirubin (T.Bil), total cholesterol (TC), total protein (TP), and albumin (Alb). 


\section{Evaluation of liver diseases}

Anti-HCV was measured using a chemiluminescent enzyme immunoassay kit (Lumipulse II HCV, Fujirebio, Tokyo, Japan). HCV RNA in serum was analyzed by the Amplicor HCV test (Roche, Tokyo, Japan) up to December 6, 2007 and by quantitative PCR assay (COBAS AMPLICOR HCV MONITOR v 2.0 Test, COBAS AmpliPrep/ COBAS Taq-Man HCV Test, Roche Molecular Systems, New Jersey, US) from December 7, 2007 [29,30]. HCV genotype was determined by polymerase chain reaction assay, using a mixture of primers for the subtype, as reported previously [31]. HBsAg was assayed using a chemiluminescent immunoassay kit (Architect, HBsAg QT, Dainabot, Tokyo, Japan). Ultrasonographic examination was performed on 59 patients and 27 control inhabitants infected with HCV in order to investigate the shape of the liver and lesions occupying the liver. Computed tomography and liver biopsy were performed on some patients. We used other possible predictors of liver cirrhosis progression, including serum Alb, T.Bil, prothrombin time, and PLT.

\section{Measurement of body weight}

Obesity was defined as a body mass index (BMI) > $25 \mathrm{~kg} / \mathrm{m}^{2}$

\section{Detection of amino acid substitutions in the core and NS5A regions}

Detection of aa substitutions in the HCV core region was performed using the method reported previously $[4,5]$ and the patients were divided into two groups on the basis of the findings. Patients with substitution of aa 70 in the core region of $\mathrm{HCV}$ were assigned to the mutant type group and patients without this substitution were assigned to the wild type group. The ISDR of NS5A was analyzed using the method reported previously [3]. Strains with no aa changes in the ISDR, with 1 to 3 aa changes, and with $>3$ aa changes were designated as wild type, intermediate type, and mutant type, respectively.

\section{Ethics considerations}

The study protocol was approved by the Ethics Committee of Kurume University (reference number: 2134-1) in accordance with the Declaration of Helsinki. Written informed consent for participation in the study was obtained from each patient.

\section{Statistical analysis}

All data are expressed as mean \pm standard error. Differences between the two groups were analyzed using the Mann-Whitney U test, Wilcoxon's test, and the Fisher's exact test. Differences were judged significant for $p<$ 0.05 (two-tailed). Adjusted odds ratios were calculated using logistic regression analysis. All statistical analyses were conducted using JMP Version 6 (SAS Institute,
Cary, NC, USA). The level of statistical significance was defined as 0.05 .

\section{Results}

Prevalence of HCV infection among patients with lichen planus: a retrospective case-control study

We compared the characteristics of group 1-A and group $1-\mathrm{B}$. The characteristics of the 144 subjects studied are shown in Table 1. The prevalence of anti-HCV and HCV RNA was $67.80 \%$ (40/59) and 59.32\% (35/59), respectively, in group 1-A and $31.76 \%(27 / 85)$ and $16.47 \%(14 / 85)$, respectively, in group 1-B. The prevalence of anti-HCV $(P<0.0001)$ and HCV RNA $(P<0.0001)$ in group 1 -A was significantly higher than those in group 1-B.

The prevalence of liver disease $(P<0.0001)$, thyroid disease $(P=0.0440)$ and history of smoking $(P=$ 0.0080 ) was significantly higher in group 1 -A than in group 1-B (Table 1).

The diagnosis of liver disease in group 1-A included: past history of HCV infection $(n=1)$, chronic hepatitis $C$ $(n=20)$, chronic hepatitis $C$ during IFN therapy $(n=4)$, SVR after IFN therapy $(n=4)$, chronic hepatitis $C$ with autoimmune hepatitis $(n=1)$, chronic hepatitis $C$ with post-treatment of HCC $(n=2)$, HCV-related liver cirrhosis $(\mathrm{n}=2)$, HCV-related liver cirrhosis with post-treatment of HCC $(n=6)$, chronic hepatitis B $(n=1)$, HBV-related liver cirrhosis $B(n=1)$, primary biliary cirrhosis $(P B C)$ $(n=1)$, fatty liver $(n=2)$, and fatty liver with alcoholic liver disease $(n=1)$. Those of group 1-B included: past history of HCV infection $(n=12)$, chronic hepatitis $C(n=$ $11)$, SVR after IFN therapy $(n=1)$, chronic hepatitis $C$ with post-treatment of HCC $(\mathrm{n}=1)$, HCV-related liver cirrhosis $(\mathrm{n}=1)$, and HCV-related liver cirrhosis with post-treatment of HCC $(n=1)$.

We analyzed the differences between these two groups in terms of laboratory values for liver function tests and PLT. As shown in Table 1, abnormal levels of AST $(P=$ $0.0009)$, ALT $(P=0.0031)$, Alb $(P<0.0001)$, T.Bil $(P<$ $0.0001)$, TC $(P=0.0007)$, and PLT $(P<0.0001)$ differed significantly between the groups.

We examined the viral load in 39 of 40 anti-HCVpositive patients, excluding one patient who cleared serum HCV RNA naturally (group 1-A). In seven patients, including during IFN therapy (4 patients) and SVR (3 of 4), the viral load was measured before IFN therapy. The HCV RNA level was high viral load (over $100 \mathrm{KIU} / \mathrm{mL}$ or $5.0 \log \mathrm{IU} / \mathrm{mL})$ in $32(82.05 \%)$ group 1A patients, low viral load (less than $100 \mathrm{KIU} / \mathrm{mL}$ or 5.0 $\log \mathrm{IU} / \mathrm{mL})$ in $3(7.69 \%)$ and unknown in $4(10.26 \%)$. All HCV RNA-positive individuals among 14 members of group 1-B had a high viral load. As for an SVR case in the group 1-B, pretreatment viral load was not clear. We also examined the HCV genotype of group 1-A; the genotype was $1 \mathrm{~b}$ in $27(77.14 \%)$ patients, $2 \mathrm{a}$ in two 
Table 1 Characteristics of study population $1(n=144)$

\begin{tabular}{|c|c|c|c|c|c|c|c|c|}
\hline Characteristics & & Total & & Group1-A & & Group1-B & & A vs. $B$ \\
\hline & & & & $\begin{array}{l}\text { with lichen } \\
\text { planus }\end{array}$ & & $\begin{array}{c}\text { with normal oral } \\
\text { mucosa }\end{array}$ & & $\begin{array}{c}P \\
\text { value }\end{array}$ \\
\hline No. subjects & & 144 & & 59 & & 85 & & \\
\hline Sex & male/female & $39 / 105$ & & $14 / 45$ & & $25 / 60$ & & NS \\
\hline Age & (mean $\pm S D)$, years & $67.05 \pm 9.87$ & & $68.05 \pm 9.93$ & & $66.35 \pm 9.83$ & & NS \\
\hline Liver disease & positive (\%) & 73 & $50.69 \%$ & 46 & $77.97 \%$ & 27 & $31.76 \%$ & $\begin{array}{c}< \\
0.0001\end{array}$ \\
\hline \multirow[t]{14}{*}{$\begin{array}{l}\text { Diagnosis of liver } \\
\text { diseases }\end{array}$} & $\begin{array}{l}\text { Past history of HCV } \\
\text { infection }\end{array}$ & 13 & $9.03 \%$ & 1 & $1.69 \%$ & 12 & $14.12 \%$ & \\
\hline & $\mathrm{CH}-\mathrm{C}$ & 31 & $21.53 \%$ & 20 & $33.90 \%$ & 11 & $12.94 \%$ & \\
\hline & $\mathrm{CH}-\mathrm{C}$ during IFN & 4 & $2.78 \%$ & 4 & $6.78 \%$ & 0 & $0.00 \%$ & \\
\hline & $\mathrm{CH}-\mathrm{C}$ post IFN (SVR) & 5 & $3.47 \%$ & 4 & $6.78 \%$ & 1 & $1.18 \%$ & \\
\hline & $\mathrm{CH}-\mathrm{C}+\mathrm{AlH}$ & 1 & $0.69 \%$ & 1 & $1.69 \%$ & 0 & $0.00 \%$ & \\
\hline & $\begin{array}{l}\mathrm{CH}-\mathrm{C}+\text { post HCV-related } \\
\mathrm{HCC}\end{array}$ & 3 & $2.08 \%$ & 2 & $3.39 \%$ & 1 & $1.18 \%$ & \\
\hline & LC-C & 3 & $2.08 \%$ & 2 & $3.39 \%$ & 1 & $1.18 \%$ & \\
\hline & $\begin{array}{l}\text { LC-C + post HCV-related } \\
\text { HCC }\end{array}$ & 7 & $4.86 \%$ & 6 & $10.17 \%$ & 1 & $1.18 \%$ & \\
\hline & $\mathrm{CH}-\mathrm{B}$ & 1 & $0.69 \%$ & 1 & $1.69 \%$ & 0 & $0.00 \%$ & \\
\hline & LC-B & 1 & $0.69 \%$ & 1 & $1.69 \%$ & 0 & $0.00 \%$ & \\
\hline & PBC & 1 & $0.69 \%$ & 1 & $1.69 \%$ & 0 & $0.00 \%$ & \\
\hline & Fatty liver & 2 & $1.39 \%$ & 2 & $3.39 \%$ & 0 & $0.00 \%$ & \\
\hline & Fatty liver + ALD & 1 & $0.69 \%$ & 1 & $1.69 \%$ & 0 & $0.00 \%$ & \\
\hline & Normal liver & 71 & $49.31 \%$ & 13 & $22.03 \%$ & 58 & $68.24 \%$ & \\
\hline Diabetes mellitus & positive (\%) & 14 & $9.72 \%$ & 6 & $10.17 \%$ & 8 & $9.41 \%$ & NS \\
\hline Thyroid disease & positive (\%) & 8 & $5.56 \%$ & 6 & $10.17 \%$ & 2 & $2.35 \%$ & 0.0440 \\
\hline $\begin{array}{l}\text { Extrahepatic malignant } \\
\text { tumor }\end{array}$ & positive (\%) & 15 & $10.42 \%$ & 5 & $8.47 \%$ & 10 & $11.76 \%$ & NS \\
\hline Smoking history & yes (\%) & 37 & $25.69 \%$ & 22 & $37.29 \%$ & 15 & $17.65 \%$ & 0.0080 \\
\hline History of alcohol intake & yes (\%) & 59 & $40.97 \%$ & 19 & $32.20 \%$ & 40 & $47.06 \%$ & NS \\
\hline Anti-HCV & positive (\%) & 67 & $46.53 \%$ & 40 & $67.80 \%$ & 27 & $31.76 \%$ & $\begin{array}{c}< \\
0.0001 \\
\end{array}$ \\
\hline HCV RNA & positive (\%) & 49 & $34.03 \%$ & 35 & $59.32 \%$ & 14 & $16.47 \%$ & $\begin{array}{c}<< \\
0.0001\end{array}$ \\
\hline \multirow[t]{3}{*}{ HCV RNA level } & High & 46 & $85.19 \%$ & 32 & $82.05 \%$ & 14 & $93.33 \%$ & NS \\
\hline & Low & 3 & $5.56 \%$ & 3 & $7.69 \%$ & 0 & $0.00 \%$ & NS \\
\hline & unexmained & 5 & $9.26 \%$ & 4 & $10.26 \%$ & 1 & $6.67 \%$ & \\
\hline \multirow[t]{4}{*}{ HCV genotype } & $1 b$ & 27 & $55.10 \%$ & 27 & $77.14 \%$ & - & & \\
\hline & $2 a$ & 2 & $4.08 \%$ & 2 & $5.71 \%$ & - & & \\
\hline & $2 b$ & 0 & $0.00 \%$ & 0 & $0.00 \%$ & - & & \\
\hline & unexmained & 20 & $40.82 \%$ & 6 & $17.14 \%$ & 14 & $100.00 \%$ & \\
\hline $\mathrm{HBsAg}$ & positive (\%) & 3 & $2.08 \%$ & 2 & $3.39 \%$ & 1 & $1.18 \%$ & NS \\
\hline $\mathrm{BMI}$ & & $22.70 \pm 3.20$ & & $22.44 \pm 3.20$ & & $22.88 \pm 3.20$ & & NS \\
\hline AST & $(\mathrm{U} / \mathrm{L})($ mean $\pm \mathrm{SD})$ & $29.71 \pm 16.86$ & & $36.09 \pm 20.33$ & & $25.65 \pm 12.78$ & & 0.0009 \\
\hline ALT & $(\mathrm{U} / \mathrm{L})($ mean $\pm \mathrm{SD})$ & $25.47 \pm 20.06$ & & $30.54 \pm 22.39$ & & $22.25 \pm 17.82$ & & 0.0031 \\
\hline $\mathrm{LDH}$ & $(\mathrm{U} / \mathrm{L})($ mean $\pm \mathrm{SD})$ & $\begin{array}{c}202.40 \pm \\
43.56\end{array}$ & & $211.42 \pm 54.63$ & & $196.88 \pm 34.34$ & & NS \\
\hline ALP & $(\mathrm{U} / \mathrm{L})($ mean $\pm \mathrm{SD})$ & $\begin{array}{c}272.76 \pm \\
112.57 \\
\end{array}$ & & $299.62 \pm 155.99$ & & $256.33 \pm 70.88$ & & NS \\
\hline TP & $(\mathrm{g} / \mathrm{dL})($ mean $\pm \mathrm{SD})$ & $7.17 \pm 0.42$ & & $7.27 \pm 0.43$ & & $7.11 \pm 0.41$ & & NS \\
\hline
\end{tabular}


Table 1 Characteristics of study population $1(n=144)$ (Continued)

\begin{tabular}{|c|c|c|c|c|c|}
\hline Alb & $(\mathrm{g} / \mathrm{dL})($ mean $\pm \mathrm{SD})$ & $4.15 \pm 0.33$ & $3.99 \pm 0.38$ & $4.26 \pm 0.25$ & $\begin{array}{c}< \\
0.0001\end{array}$ \\
\hline T.Bil & $(\mathrm{mg} / \mathrm{dL})($ mean $\pm \mathrm{SD})$ & $1.13 \pm 5.27$ & $2.03 \pm 8.57$ & $0.60 \pm 0.20$ & $\begin{array}{c}< \\
0.0001\end{array}$ \\
\hline TC & $(\mathrm{mg} / \mathrm{dL})($ mean $\pm \mathrm{SD})$ & $\begin{array}{c}192.34 \pm \\
35.28 \\
\end{array}$ & $179.12 \pm 37.18$ & $200.12 \pm 31.84$ & 0.0007 \\
\hline $\mathrm{Hb}$ & $(\mathrm{g} / \mathrm{dL})($ mean $\pm \mathrm{SD})$ & $13.30 \pm 1.39$ & $13.16 \pm 1.39$ & $13.39 \pm 1.38$ & NS \\
\hline PLT & $(/ \mu \mathrm{L})($ mean $\pm \mathrm{SD})$ & $18.30 \pm 5.57$ & $15.95 \pm 6.42$ & $19.71 \pm 4.48$ & $\begin{array}{c}< \\
0.0001\end{array}$ \\
\hline
\end{tabular}

$H C V$, hepatitis $C$ virus; $C H$ - , chronic hepatitis $C$; $L C-C$, liver cirrhosis type $C ; H C C$, hepatocellular carcinoma; $C H$ - $B$, chronic hepatitis $B$; $L C$ - $B$, liver cirrhosis type $B$; $A I H$, autoimmune hepatitis; $P B C$, primary biliary cirrhosis; $A L D$, alcoholic liver disease; IFN, interferon; $N S$, not significant; $A S T$, aspartate aminotransferase; $A L T$, alanine aminotransferase; $L D H$, lactate dehydrogenase; $A L P$, alkaline phosphatase; TP, total protein; Alb, albumin; T.Bil, total bilirubin; TC, total cholesterol; PLT, platelets

(5.71\%), and unknown in 6 (17.14\%). The genotype of group 1-B was not measured.

\section{Multivariate analysis}

In multivariable analysis, all variables in the univariable analyses were included. According to multivariate analysis, three factors, positivity for HCV RNA, low albumin level $(<4.0 \mathrm{~g} / \mathrm{dL})$, and history of smoking, were associated with the development of lichen planus. The adjusted odds ratios for these three factors were 6.58, 3.53 and 2.58 , respectively, and each was statistically significant (Table 2).

Detection amino acid substitutions in the HCV core region and ISDR of NS5A among $\mathrm{HCV}$-infected patients with lichen planus and those without

In the present study, aa substitutions in the core region (70 and/or 91) and ISRR of NS5A were analyzed by direct sequencing in $19 \mathrm{HCV}$-infected patients with lichen planus and those without [3-5] (Table 3). No significant differences were seen between the two groups (groups 2-A and -B).

\section{Discussion}

In this study, we demonstrated that $\mathrm{HCV}$ infection is significantly associated with the development of lichen planus. The odds ratio was 6.58 (95\% confidence interval 2.89-15.69). This odds ratio was higher than that of a meta-analysis published recently (odds ratio 2.8) [32]. Hypoalbuminemia and smoking also increased the risk of lichen planus. However, substitutions of aa 70 and/or 91 and ISDR regions had no impact on the development of lichen planus.
HCC is one of the most common malignancies, especially in Japan. The most important risk factors of HCC are chronic hepatitis C, B and cirrhosis. The effect of PegIFN and ribavirin (RBV) treatment on chronic HCV infection has been established in several controlled clinical studies [33]. The effects of IFN are summarized as follows: elimination of $\mathrm{HCV}$, reduction of hepatic inflammation, improvement in liver fibrosis, and reduction in hepatocarcinogenesis [34]. In Japan, 70\% of refractory cases are infected with genotype $1 \mathrm{~b}$ with a high HCV RNA load. Japanese patients with chronic HCV infection are getting older. Viral mutations leading to aa substitutions in the $\mathrm{HCV}$ core region (70 and/or 91) and ISDR of NS5A have been shown to be valuable as predictors of virological response to combination therapy with Peg-IFN and RBV [2-6]. In addition, single nucleotide polymorphisms (SNPs) around the human interleukin 28B (IL28B) gene locus have been reported to affect the efficacy of Peg-IFN and RBV therapy in chronic hepatitis with HCV genotype $1 \mathrm{~b}$ infection $[35,36]$. In Japan, there is an established standard therapy for chronic hepatitis $\mathrm{C}$ based on guidelines including viral factors such as genotype and levels of HCV RNA. More recently, the effects of variation of IL28B and aa substitutions in the HCV core region and ISDR of NS5A have been established.

The association between lichen planus and HCV infection seems to be more common in individuals living in areas of Japan and Italy [11-13]. The difference in the prevalence $\mathrm{HCV}$-infection in patients with lichen planus seems to be due to geographic differences in HCV infection, selection of study subjects such as sex, average age, and diagnosis in the respective countries, and some genetic predisposition such as the HLA-DR6

Table 2 Factors associated with lichen planus according to multivariate analysis

\begin{tabular}{lccc}
\hline & Adjusted odds ratio & (95\% confidence interval) & P value \\
\hline HCV RNA positive & 6.58 & $(2.89-15.69)$ & $<0.0001$ \\
Albumin $<4.0 \mathrm{~g} / \mathrm{dL}$ & 3.53 & $(1.42-9.05)$ & 0.0072 \\
History of smoking (yes) & 2.58 & $(1.05-6.48)$ & 0.0396 \\
\hline
\end{tabular}


Table 3 Characteristics of study population $2(n=19)$

\begin{tabular}{|c|c|c|c|c|c|}
\hline Characteristics & & & $\begin{array}{l}\text { Group2-A } \\
\text { with lichen planus } \\
(\mathrm{n}=12)\end{array}$ & $\begin{array}{l}\text { Group2-AB } \\
\text { without lichen } \\
\text { planus }(n=7) \\
\end{array}$ & $\begin{array}{c}P \\
\text { value }\end{array}$ \\
\hline Age (mean $\pm S D)$, years & & & $64.83 \pm 7.51$ & $63.86 \pm 10.57$ & NS \\
\hline Sex (male/female) & & & $4 / 8$ & $1 / 6$ & NS \\
\hline \multirow[t]{2}{*}{ Diagnosis of liver diseases } & $\mathrm{CH}-\mathrm{C}(\mathrm{CH}-\mathrm{C}$ post $\mathrm{HCC})$ & & $10(2), 83.33 \%$ & $7(100 \%)$ & NS \\
\hline & LC-C (LC-C post HCC) & & $2(1), 16.67 \%$ & $0(0 \%)$ & NS \\
\hline \multirow[t]{7}{*}{ Viral factors } & HCV RNA level (loglU/mL) & High & $12(100 \%)$ & $7(100 \%)$ & NS \\
\hline & HCV genotype & $1 b$ & $12(100 \%)$ & $7(100 \%)$ & NS \\
\hline & $\begin{array}{l}\text { Amino acid substitutions in } \\
\text { the core region }\end{array}$ & aa 70 (wild type/non-wild) & $\begin{array}{l}5 / 7(41.67 \% / \\
58.33 \%)\end{array}$ & $2 / 5(28.57 \% / 71.43 \%)$ & NS \\
\hline & & aa 91 (wild type/non-wild) & $\begin{array}{l}6 / 6(50.00 \% / \\
50.00 \%)\end{array}$ & $5 / 2(71.43 \% / 28.57 \%)$ & NS \\
\hline & & $\begin{array}{l}\text { aa } 70 \text { and } 91 \text { (double-wild type/non- } \\
\text { double-wild type) }\end{array}$ & $\begin{array}{l}3 / 9(25.00 \% / \\
75.00 \%)\end{array}$ & $1 / 6(14.29 \% / 85.71 \%)$ & NS \\
\hline & Number of ISDR substituions & 0 (wild type) & $8(66.67 \%)$ & $3(42.86 \%)$ & NS \\
\hline & & 1-3 (intermediate type) & $4(33.33 \%)$ & $4(57.14 \%)$ & NS \\
\hline $\begin{array}{l}\text { Effect of previous IFN } \\
\text { therapy (non-SVR) }\end{array}$ & & & $12(100 \%)$ & $7(100 \%)$ & NS \\
\hline
\end{tabular}

$H C V$, hepatitis C virus; $C H-C$, chronic hepatitis C; LC-C, liver cirrhosis type C; HCC, hepatocellular carcinoma; IFN, interferon; SVR, sustained virological response; ISDR, IFN sensitivity-determining region; NS, not significant

allele. The HLA-DR6 allele is reported to be significantly more common in Italian patients with lichen planus and HCV [37]. Moreover, not all reported studies included screening of hepatic damage and measurement of serum HCV RNA to determine the presence or absence of hepatic diseases. The areas of our study are in the northern Kyushu region, where the HCV infection rate and the mortality rate from $\mathrm{HCC}$ are the highest in Japan. Previous reports indicated that there are no differences in the viral factors such as viral load and genotype between $\mathrm{HCV}$-infected patients with lichen planus and those without $[17,18]$. This study ruled out a direct association of viral factors, such as substitutions of aa 70 and/or 91 and in the ISDR region, with the development of HCV-related lichen planus.

We reported that the prevalence of HCV-related lichen planus increased as the subjects grew older in Japan [38]. We also reported previously the prevalence of HCV infection among lichen planus among 45 patients who visited the Department of Oral Surgery at our hospital from November 1993 to April 1994 [12]. The mean age (68.1 years) of the 59 patients (group 1A) in the present study was higher than that (61.1 years) of the previous 45 patients.

We demonstrated a strong association between hypoalbuminemia and mortality in a hyperendemic area (X town) of HCV infection in Japan [39]. Residents with hypoalbuminemia had a mortality of $68.0 \%$; dramatically higher than the rate of $12.1 \%$ among residents who had normal albumin levels. Hypoalbuminemia was an independent risk factor for the development of lichen planus. Recent studies have demonstrated the efficacy of branched-chain amino acid (BCAA) supplementation in improving hypoalbuminemia in cirrhotic patients [40]. The effects of BCAA intake have been investigated in a number of disease models, including obesity and metabolic disorders, liver disease, impaired immunity, muscle atrophy, cancer, and a variety of injury (postoperative, trauma, burn, and sepsis) [41]. Among Japan's aging population, BCAA intake seems to be useful for HCVinfected patients with lichen planus.

\section{Conclusion}

In conclusion, our data show that $\mathrm{HCV}$ infection could be the main pathogenic factor of lichen planus in Japanese patients. Routine HCV testing and medical examination for lichen planus are recommended for patients in high-risk HCV areas like Japan. Further investigation is required to clarify the mechanisms of development of HCV-related lichen planus.

\section{Source of support}

This study was supported in part by a Grant-in-Aid for Scientific Research (C) (No.22592354) from the Ministry of Education, Culture, Sports, Science and Technology of Japan.

\section{Abbreviations}

HCV: Hepatitis C virus; CH-C: Chronic hepatitis C; $\mathrm{CH}-\mathrm{B}$ : Chronic hepatitis B: LC-C: Liver cirrhosis type C; LC-B: Liver cirrhosis type B; HCC: Hepatocellular carcinoma; PBC: Primary biliary cirrhosis; IFN: Interferon; RBV: Ribavirin; SVR: Sustained virological response; NVR: Non-virological response; aa: Amino acids; ISDR: IFN-sensitivity-determining region; NS5A: Nonstructural protein 5A; PLT: Platelets; Hb: Hemoglobin; ALT: Alanine aminotransferase; AST: Aspartate aminotransferase; LDH: Lactate dehydrogenase; ALP: Alkaline 
phosphatase; T.Bil: Total bilirubin; TC: Total cholesterol; TP: Total protein; Alb: Albumin

\section{Author details}

'Department of Digestive Disease Information \& Research, Kurume University School of Medicine, Kurume, Fukuoka 830-0011, Japan. ²Division of Gastroenterology, Department of Medicine, Kurume University School of Medicine, Kurume, Fukuoka 830-0011, Japan.

\section{Authors' contributions}

YN carried out most of the data collection and drafted the manuscript. MS contributed to data analysis. All authors read and approved the final manuscript.

\section{Competing interests}

The authors declare that they have no competing interests.

Received: 25 November 2011 Accepted: 10 April 2012 Published: 10 April 2012

\section{References}

1. Asahina Y, Tsuchiya K, Tamaki N, Hirayama I, Tanaka T, Sato M, Yasui Y, Hosokawa T, Ueda K, Kuzuya T, Nakanishi H, Itakura J, Takahashi Y, Kurosaki M, Enomoto N, Izumi N: Effect of aging on risk for hepatocellular carcinoma in chronic hepatitis C virus infection. Hepatology 2010, 52:518-527.

2. Enomoto N, Sakuma I, Asahina Y, Kurosaki M, Murakami T, Yamamoto C, Izumi N, Marumo F, Sato C: Comparison of full-length sequences of interferon-sensitive and resistant hepatitis $C$ virus $1 \mathrm{~b}$. Sensitivity to interferon is conferred by amino acid substitutions in the NS5A region. $J$ Clin Invest 1995, 96:224-230.

3. Enomoto N, Sakuma I, Asahina Y, Kurosaki M, Murakami T, Yamamoto C, Ogura $Y$, Izumi N, Marumo F, Sato C: Mutations in the nonstructural protein $5 \mathrm{~A}$ gene and response to interferon in patients with chronic hepatitis C virus 1b infection. N Engl J Med 1996, 334:77-81.

4. Akuta N, Suzuki F, Sezaki H, Suzuki Y, Hosaka T, Someya T, Kobayashi M, Saitoh S, Watahiki S, Sato J, Matsuda M, Kobayashi M, Arase Y, Ikeda K, Kumada $\mathrm{H}$ : Association of amino acid substitution pattern in core protein of hepatitis $C$ virus genotype $1 \mathrm{~b}$ high viral load and nonvirological response to interferon-ribavirin combination therapy. Intervirology 2005, 48:372-380

5. Akuta N, Suzuki F, Kawamura Y, Yatsuji H, Sezaki H, Suzuki Y, Hosaka T, Kobayashi M, Kobayashi M, Arase Y, Ikeda K, Kumada H: Predictive factors of early and sustained responses to peginterferon plus ribavirin combination therapy in Japanese patients infected with hepatitis $C$ virus genotype $1 \mathrm{~b}$ : amino acid substitutions in the core region and lowdensity lipoprotein cholesterol levels. J Hepatol 2007, 46:403-410.

6. Akuta N, Suzuki F, Kawamura Y, Yatsuji H, Sezaki H, Suzuki Y, Hosaka T, Kobayashi M, Kobayashi M, Arase Y, Ikeda K, Kumada H: Amino acid substitutions in the hepatitis $C$ virus core region are the important predictor of hepatocarcinogenesis. Hepatology 2007, 46:1357-1364.

7. Gumber SC, Chopra S: Hepatitis C: A multifaceted disease. Review of extrahepatic manifestations. Ann Intern Med 1995, 123:615-620.

8. Pawlotsky JM, Ben Yahia M, Andre C, Voisin MC, Intrator L, RoudotThoraval F, Deforges L, Duvoux C, Zafrani ES, Duval J: Immunological disorders in $C$ virus chronic active hepatitis: a prospective case-control study. Hepatology 1994, 19:841-848.

9. Cacoub P, Renou C, Rosenthal E, Cohen P, Loury I, Loustaud-Ratti V, Yamamoto AM, Camproux AC, Hausfater P, Musset L, Veyssier P, Raguin G, Piette JC: Extrahepatic manifestations associated with hepatitis $C$ virus infection. A prospective multicenter study of 321 patients. The GERMIVIC. Groupe d'Etude et de Recherche en Medecine Interne et Maladies Infectieuses sur le Virus de I'Hepatite C. Medicine (Baltimore) 2000, 79:47-56.

10. El-Serag HB, Hampel H, Yeh C, Rabeneck L: Extrahepatic manifestations of hepatitis C among United States male veterans. Hepatology 2002, 36:1439-1445.

11. Jubert C, Pawlotsky JM, Pouget F, Andre C, DeForges L, Bretagne S, Mavier JP, Duval J, Revuz J, Dhumeaux D, Bagot M: Lichen planus and hepatitis C virus-related chronic active hepatitis. Arch Dermatol 1994, 130:73-76
12. Nagao Y, Sata M, Tanikawa K, Itoh K, Kameyama T: Lichen planus and hepatitis $C$ virus in the northern Kyushu region of Japan. Eur J Clin Invest 1995, 25:910-914

13. Carrozzo M, Gandolfo S, Carbone M, Colombatto P, Broccoletti R, GarzinoDemo $P$, Ghisetti V: Hepatitis $C$ virus infection in Italian patients with oral lichen planus: a prospective case-control study. J Oral Pathol Med 1996, 25:527-533.

14. Bagán JV, Ramón C, González L, Diago M, Milián MA, Cors R, Lloria E, Cardona $F$, Jiménez $Y$ : Preliminary investigation of the association of oral lichen planus and hepatitis C. Oral Surg Oral Med Oral Pathol Oral Radiol Endod 1998, 85:532-536.

15. Figueiredo LC, Carrilho FJ, de Andrage HF, Migliari DA: Oral lichen planus and hepatitis $C$ virus infection. Oral Dis 2002, 8:42-46.

16. Carrozzo M: Oral diseases associated with hepatitis $C$ virus infection. Part 2: Lichen Planus and other diseases. Oral Dis 2008, 14:217-228.

17. Nagao Y, Sata M, Itoh K, Tanikawa K, Kameyama T: Quantitative analysis of HCV RNA and genotype in patients with chronic hepatitis C accompanied by oral lichen planus. Eur J Clin Invest 1996, 26:495-498.

18. Lodi G, Carrozzo M, Hallett R, D'Amico E, Piattelli A, Teo CG, Gandolfo S, Carbone M, Porter SR: HCV genotypes in Italian patients with HCV-related oral lichen planus. J Oral Pathol Med 1997, 26:381-384.

19. Sata M, Nakano H, Suzuki H, Noguchi S, Yamakawa Y, Tanaka E, Fukuizumi K, Tanaka K, Yoshida H, Tanikawa K: Sero-epidemiologic study of hepatitis C virus infection in Fukuoka, Japan. J Gastroenterol 1998, 33:218-222.

20. Fukuizumi K, Sata M, Suzuki H, Nakano H, Tanikawa K: Hepatitis C virus seroconversion rate in a hyper-endemic area of HCV in Japan: a prospective study. Scand J Infect Dis 1997, 29:345-347.

21. Fukuizumi K, Sata M, Suzuki H, Kumashiro R, Tanikawa K: Natural disappearance of serum HCV RNA; prospective study in a hyperendemic area. Hepatol Res 1997, 9:144-151

22. Noguchi S, Sata M, Suzuki H, Mizokami M, Tanikawa K: Routes of transmission of hepatitis $C$ virus in an endemic rural area of Japan. Molecular epidemiologic study of hepatitis C virus infection. Scand J Infect Dis 1997, 29:23-28.

23. Nagao $Y$, Fukuizumi $K$, Tanaka K, Kumashiro R, Sata M: The prognosis for life in an HCV hyperendemic area. Gastroenterology 2003, 125:628-629.

24. Nagao $Y$, Tanaka K, Kobayashi $K$, Kumashiro R, Sata M: A cohort study of chronic liver disease in an HCV hyperendemic area of Japan: a prospective analysis for 12 years. Int J Mol Med 2004, 13:257-265.

25. Nagao Y, Tanaka K, Kobayashi K, Kumashiro R, Sata M: Analysis of approach to therapy for chronic liver disease in an HCV hyperendemic area of Japan. Hepatol Res 2004, 28:30-35.

26. Nagao Y, Sata M, Fukuizumi K, Tanikawa K, Kameyama T: High incidence of oral precancerous lesions in a hyperendemic area of hepatitis $C$ virus infection. Hepatol Res 1997, 8:173-177.

27. Nagao $Y$, Sata $M$, Fukuizumi $K$, Ryu $F$, Ueno T: High incidence of oral lichen planus in an HCV hyperendemic area. Gastroenterology 2000, 119:882-883.

28. Nagao Y, Kawaguchi T, Tanaka K, Kumashiro R, Sata M: Extrahepatic manifestations and insulin resistance in an HCV hyperendemic area. Int $J$ Mol Med 2005, 16:291-296.

29. Lee SC, Antony A, Lee N, Leibow J, Yang JQ, Soviero S, Gutekunst K, Rosenstraus M: Improved version 2.0 qualitative and quantitative AMPLICOR reverse transcription-PCR tests for hepatitis $C$ virus RNA: calibration to international units, enhanced genotype reactivity, and performance characteristics. J Clin Microbiol 2000, 38:4171-4179.

30. Sizmann D, Boeck C, Boelter J, Fischer D, Miethke M, Nicolaus S, Zadak M, Babiel R: Fully automated quantification of hepatitis C virus (HCV) RNA in human plasma and human serum by the COBAS AmpliPrep/COBAS TaqMan system. J Clin Virol 2007, 38:326-333.

31. Dusheiko G, Schmilovitz-Weiss H, Brown D, McOmish F, Yap PL, Sherlock S, Mclntyre N, Simmonds P: Hepatitis C virus genotypes: an investigation of type-specific differences in geographic origin and disease. Hepatology 1994, 19:13-18

32. Petti S, Rabiei M, De Luca M, Scully C: The magnitude of the association between hepatitis $C$ virus infection and oral lichen planus: meta-analysis and case control study. Odontology 2011, 99:168-178.

33. Antonucci G, Longo MA, Angeletti C, Vairo F, Oliva A, Comandini UV, Tocci G, Boumis E, Noto P, Solmone MC, Capobianchi MR, Girardi E: The effect of age on response to therapy with peginterferon alpha plus 
ribavirin in a cohort of patients with chronic HCV hepatitis including subjects older than 65 yr. Am J Gastroenterol 2007, 102:1383-1391.

34. Yoshida H, Arakawa Y, Sata M, Nishiguchi S, Yano M, Fujiyama S, Yamada G, Yokosuka O, Shiratori Y, Omata M: Interferon therapy prolonged life expectancy among chronic hepatitis C patients. Gastroenterology 2002, 123:483-491.

35. Tanaka Y, Nishida N, Sugiyama M, Kurosaki M, Matsuura K, Sakamoto N, Nakagawa M, Korenaga M, Hino K, Hige S, Ito Y, Mita E, Tanaka E, Mochida S, Murawaki Y, Honda M, Sakai A, Hiasa Y, Nishiquchi S, Koike A, Sakaida I, Imamura M, Ito K, Yano K, Masaki N, Sugauchi F, Izumi N, Tokunaga K, Mizokami M: Genome-wide association of IL28B with response to pegylated interferon-alpha and ribavirin therapy for chronic hepatitis C. Nat Genet 2009, 41:1105-1109.

36. Ge D, Fellay J, Thompson AJ, Simon JS, Shianna KV, Urban TJ, Heinzen EL, Qiu P, Bertelsen AH, Muir AJ, Sulkowski M, McHutchison JG, Goldstein DB: Genetic variation in IL28B predicts hepatitis $C$ treatment-induced viral clearance. Nature 2009, 461:399-401.

37. Carrozzo M, Francia Di Celle P, Gandolfo S, Carbone M, Conrotto D, Fasano ME, Roggero S, Rendine $S$, Ghisetti V: Increased frequency of HLADR6 allele in Italian patients with hepatitis $C$ virus-associated oral lichen planus. Br J Dermatol 2001, 144:803-808.

38. Nagao Y, Myoken Y, Katayama K, Tanaka J, Yoshizawa H, Sata M: Epidemiological survey of oral lichen planus among HCV-infected inhabitants in a town in Hiroshima Prefecture in Japan from 2000 to 2003. Oncol Rep 2007, 18:1177-1181.

39. Nagao Y, Sata M: Serum albumin and mortality risk in a hyperendemic area of HCV infection in Japan. Virol J 2010, 7:375.

40. Italian BCAA Study Group, Marchesini G, Bianchi G, Merli M, Amodio P, Panella C, Loguercio C, Rossi Fanelli F, Abbiati R: Nutritional supplementation with branched-chain amino acids in advanced cirrhosis: A double blind, randomized trial. Gastroenterology 2003, 124:1792-1801.

41. Cynober L, Harris RA: Symposium on branched-chain amino acids: conference summary. J Nutr 2006, 136(1 Suppl):333S-336S.

\section{Pre-publication history}

The pre-publication history for this paper can be accessed here: http://www.biomedcentral.com/1471-230X/12/31/prepub

doi:10.1186/1471-230X-12-31

Cite this article as: Nagao and Sata: A retrospective case-control study of hepatitis $C$ virus infection and oral lichen planus in Japan: association study with mutations in the core and NS5A region of hepatitis C virus. BMC Gastroenterology 2012 12:31.

\section{Submit your next manuscript to BioMed Central and take full advantage of:}

- Convenient online submission

- Thorough peer review

- No space constraints or color figure charges

- Immediate publication on acceptance

- Inclusion in PubMed, CAS, Scopus and Google Scholar

- Research which is freely available for redistribution

Submit your manuscript at www.biomedcentral.com/submit
Biomed Central 